\title{
Indicação e intermediação de interesses: uma análise da conexão eleitoral na cidade do Rio de Janeiro, 2001-2004
}

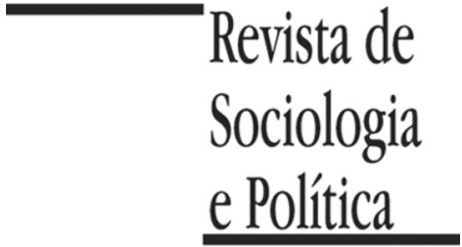

\author{
Paulo M. D’Ávila Filho, Paulo Cesar G. de Cerqueira Lima e Vladimyr Lombardo Jorge
}

\section{RESUMO}

Neste trabalho, os autores analisam a relação entre a sociedade e o poder público a partir do Poder Legislativo, tomando como objeto de estudo as indicações feitas pelos vereadores da Câmara Municipal do Rio de Janeiro aos órgãos da Prefeitura deste município nesse período. O objetivo é analisar a dinâmica político-eleitoral a partir das estratégias adotadas pelos vereadores para se reelegerem ou se elegerem para outro cargo público. A hipótese da pesquisa é que os legisladores municipais utilizam as indicações para intermediar a relação entre os eleitores e o Poder Executivo e, desta forma, construir sua conexão eleitoral. Os dados utilizados na pesquisa são secundários e qualitativos, constituindo uma base em Access (Microsoft) proveniente do Banco de indicações dos vereadores do Rio de Janeiro (Câmara Municipal do Rio de Janeiro, 2004). Seu conteúdo constitui-se de características das indicações produzidas pelos vereadores no período 2001-2004, tais como o ano de emissão e a zona de destino na cidade. A base, transportada para o Excel, foi depurada e nela cada indicação foi categorizada conforme a sua destinação a um serviço de investimento, de manutenção ou imaterial. As tabelas de frequências simples e de contingência foram geradas no pacote SPSS. Os dados característicos das indicações foram associados e identificaram-se padrões de emissão de ordens temporal, de categoria e de região de destinação. As indicações disponíveis são a totalidade daquelas emitidas pela Câmara do Rio no período mencionado. Constituem, ao mesmo tempo, uma população analisada em um período definido e uma grande amostra do processo histórico amplo e dinâmico de geração de indicações.Submetidos à análise descritiva e ao teste $\chi^{2}$ de aderência, os dados confirmam parcialmente a hipótese da pesquisa. Em primeiro lugar, eles sugerem que os vereadores tendem a usar as indicações de modo que o bem ou serviço público seja realizado pelo Executivo e entregue à população ainda durante o período de seu mandato. Em segundo, que ao fazê-las os vereadores visam fornecer um bem ou prestar um serviço público que supre as carências identificadas por eles próprios ou pelos eleitores. A pesquisa sugere que as indicações, comumente vistas como pouco relevantes por alguns cientistas políticos e a imprensa de um modo geral, podem ser instrumentos de costura de redes políticas, sendo, por isso, importante a sua análise. Mas os dados sugerem ainda a necessidade de novas pesquisas para verificar se as indicações são de fato destinadas preferencialmente ao reduto eleitoral do vereador e para se entender melhor por que nem todos os vereadores usam as indicações com a mesma frequência. A hipótese, ainda a ser verificada, é: políticos com uma votação mais concentrada territorialmente tenderiam a utilizar mais este dispositivo legislativo do que aqueles que têm uma votação mais dispersa?

PALAVRAS-CHAVE: Câmara Municipal; conexão eleitoral; intermediação de interesses; relação entre Executivo e Legislativo; representação política

Recebido em 6 de Agosto de 2012. Aprovado em 5 de Novembro de 2012.

\section{Introduçãa ${ }^{1}$}

\footnotetext{
${ }^{1}$ Esta é uma versão ampliada e modificada do trabalho "Produção legislativa e intermediação de interesses: uma análise das Indicações na Câmara Municipal do Rio de Janeiro", apresentado, em outubro de 2011, no Grupo de Trabalho "Estudos Legislativos
}

$\mathrm{E}$ ste artigo é produto de uma pesquisa que dá continuidade a uma agenda de trabalho iniciada em 2002, em torno da atividade legislativa municipal no estado do Rio de Janeiro ${ }^{2}$. O foco agora é analisar a dinâmica político-eleitoral na cidade do Rio de Janeiro a partir das estratégias adotadas pelos vereadores em seu comportamento legislativo. A questão é saber quais os recursos utilizados pelo vereador para a construção de sua rede políticoeleitoral. Os vereadores desempenham não apenas funções formais, tais como 
durante a realização", do $35^{\circ}$ Encontro Anual da Anpocs. Agradecemos às alunas Tábata Lisbôa Maia Leite, Antônio Pedro Cavalcante de Barros e Clara Gomberg Faulhaber do Vale por terem colaborado com empenho e dedicação na organização do banco de dados. Fazemos um agradecimento especial às alunas bolsistas de iniciação científica Talita São Thiago (CNPq/Pibic) e Fernanda Antunes Lopes (Faperj) pelo intenso trabalho de alimentação do nosso banco de dados com a desagregação de informações das 21008 indicações. Agradecemos ainda à professora Alessandra Maia Terra de Faria (Pontifícia Universidade Católica do Rio de Janeiro, PUC-Rio) por ter lido e criticado a primeira versão deste trabalho. Agradecemos as considerações e críticas dos pareceristas anônimos da Revista de Sociologia e Política, que analisaram o texto ora apresentado, colaborando de modo fundamental para incrementar o argumento do artigo. Várias de suas recomendações foram incorporadas ao texto. Por fim, mas não menos importante, queremos agradecer à a de legislar, julgar, fiscalizar e administrar, mas também a função informal de intermediar interesses "paroquiais" 3 . O dispositivo legislativo chamado "indicação" é um rico instrumento de verificação do caráter territorial da representação. Para além de nossas definições canônicas, a observação desses padrões de troca política sugere outras concepções de representação adotadas pelos atores políticos envolvidos.

De um ponto de vista regimental, a indicação é um dispositivo parlamentar que faculta ao vereador a possibilidade de contribuir com a administração pública realizada pelo poder Executivo por meio do envio de sugestões de prestação de serviços de interesse público ao prefeito ou ao órgão administrativo cabível. As indicações não têm a força legal de um projeto de lei ou de resolução, não precisam ser submetidas a um processo de aprovação na Câmara, mas passam por procedimentos formais: são lidas, registradas em ata, protocoladas e cadastradas como produção legislativa do vereador, documentando, assim, sua autoria. Trata-se, contudo, de uma sugestão que pode ou não ser atendida pela Prefeitura, sem que esta tenha de prestar contas formalmente por sua decisão. Dessa forma, qual seria a importância de tal iniciativa parlamentar? Por que os vereadores (em sua maioria) dedicam parte substantiva de sua produção à elaboração de um dispositivo que não tem força de lei? Essas questões preliminares são os objetivos centrais deste trabalho. A formalização e a garantia do certificado de autoria são fundamentais para o argumento que será desenvolvido em torno da importância deste instrumento na dinâmica política local.

Este estudo propõe uma reflexão sobre as indicações, lançando algumas hipóteses de interpretação de sua importância na competição política local e do seu uso por parte dos vereadores.

\section{Representações sobre a representação política}

Coordenação de Aperfeiçoamento de Pessoal de Nível Superior (Capes) e o Conselho Nacional de Desenvolvimento Científico e Tecnológico (CNPq) por terem apoiado, por meio de bolsa e de financiamento, a pesquisa que originou este trabalho.

${ }^{2}$ Damos continuidade, assim, à pesquisa realizada anteriormente em três municípios fluminenses: Mangaratiba, Niterói e Petrópolis. Trata-se da pesquisa "Gestão Pública e Mecanismos de Intermediação de Interesses Público/ Privado nos Municípios do Estado do Rio de Janeiro", realizada no Departamento de Sociologia e Política da PUC-Rio, sob a coordenação do Professor Paulo M. D'Ávila Filho, financiada pela Fundação de Amparo à Pesquisa do Estado do Rio de Janeiro (Faperj), por meio de "Prêmio Jovens Cientistas do Nosso Estado" e pelo Conselho Nacional de Desenvolvimento Científico e Tecnológico $(\mathrm{CNPq})$, por intermédio
É sugestivo o recurso à polissemia do termo representação no trabalho clássico de Hanna Pitkin. Em sua introdução, Pitkin trata das diferentes concepções que a palavra representação pode abarcar na língua inglesa. A autora nos lembra que os seres humanos não são apenas animais que se organizam politicamente, mas também animais articuladores de linguagem. Seus comportamentos são moldados por suas ideias. O que fazem, e como fazem, dependerá de como veem a si mesmos e o seu mundo, e isto, por outro lado, dependerá dos conceitos por meio dos quais eles veem (Pitkin 1967, p. 6). O ponto central é o que a representação é ou parece ser, o que não está separado da questão sobre o que a representação significa.

Na perspectiva que estamos adotando, a questão em torno do significado da representação afasta-se do dever ser canônico e normativo que marca os preceitos constitucionais ou o debate teórico da área. Encontramo-nos no âmbito do que poderíamos chamar de "representações sobre a ideia de representação". Para além do debate normativo em torno do significado da representação e dos arranjos institucionais ou regras que poderiam levar-nos a uma suposta melhor representação, nosso estudo concentra-se no que chamamos de "representações em uso" em clara alusão à ideia clássica de "linguagem em uso" de Wittgenstein (1994), tão bem explorada por MacIntyre (1991). Nessa chave, a linguagem é uma construção intersubjetiva, socialmente produzida. Para que haja comunicação é necessário que compartilhemos os sentidos das palavras no que podemos chamar de "língua em uso", a despeito de sua significação vernácula. As palavras, em uma linguagem pública, adquirem seu sentido pu- 
do Programa de Bolsas Pibic. Pudemos notar que, nesses três municípios, além das emendas ao orçamento, o instrumento chamado de indicação marca a relação entre o poder Legislativo, o poder Executivo e o eleitorado, no que diz respeito à distribuição dos recursos públicos. (D'Ávila Filho, Alves \& Jorge 2002)

${ }^{3}$ As primeiras, que estamos chamando de funções formais, são assim chamadas porque estão previstas formalmente na legislação. As segundas foram denominadas de "informais" porque não são previstas, contudo, são tão importantes quanto as primeiras para os vereadores, pois delas depende também a continuidade ou não da carreira do representante.

${ }^{4}$ Em um estudo do perfil dos vereadores, criamos cinco tipos ideais que correspondem às ênfases que os próprios vereadores atribuíram à sua atividade legislativa: o universalista, o gestor público, o comunitário, o paroquial e o assistencial (D'Avila 2005). blicamente, ao serem associadas a condições publicamente acessíveis que asseguram sua aplicação. Tais condições determinarão não somente seu sentido, mas também sua referência.

A ideia em uso da representação, em nossa perspectiva, será formada a partir do jogo de ofertas e procuras no mercado político. Diversos sentidos e usos para a representação são oferecidos pelos vereadores a partir das suas distintas estratégias de ação legislativa e extralegislativa ${ }^{4}$. A representação de interesses paroquiais é apenas uma delas, que podem ser apreendidas no estudo das indicações.

Segundo Michel De Certeau: "A presença e a circulação de uma representação (ensinada como código de promoção sócio-econômica por pregadores, por educadores ou por vulgarizadores) não indicam de modo algum o que ela é para seus usuários. É ainda necessário analisar a sua manipulação pelos praticantes que não a fabricam. Só então é que se pode apreciar a diferença ou a semelhança entre produção da imagem e a produção secundária que se esconde nos processos de sua utilização" (De Certeau 1994, p. 40).

Esse é o sentido da observação das representações sobre a ideia de representação. Pretendemos buscá-las nos seus usos ordinários, cotidianos.

Em clara sintonia com Foucault (1984), De Certeau (1994) distingue dois planos das representações sociais: um que denomina de estratégia e outro de tática. A dimensão estratégica é a feição normativa, disciplinar, institucionalizada de uma representação, como sua definição pelo especialista. A dimensão tática reside na forma como os usuários criarão seus mecanismos de uso e proveito da dimensão disciplinar (estratégica). Os consumidores usuários reagem às normas, ocasião em que, embora não produtores, tirarão proveito das forças que lhes são estranhas. Trata-se de uma espécie de produção de novos significados, frequentemente díspares do sentido atribuído disciplinarmente. Assim sendo, os consumidores usuários das normas não são agentes passivos, mas ativos recriadores de significados, tais como nossos eleitores no mercado político.

Foucault reconhece todo o poder disciplinar que anima o seu contrário, as forças que dele escapam. Enquanto Foucault concentrou-se no poder disciplinar, De Certeau desloca-se para os pontos de fuga e contrapoder, as táticas. Em nosso caso, tal como um antropólogo olha para a lata de lixo de uma casa para observar seus padrões de consumo, nós olhamos para uma categoria marginal da atividade legislativa para observar as táticas, as representações em uso do jogo político local, por intermédio da interação ordinária entre detentores de recursos de autoridade e demandantes de toda ordem de benefícios públicos. Essa é a razão de ser do estudo, ainda em andamento, das indicações.

\section{Um novo objeto de pesquisa: as indicações}

O tema das trocas políticas e das redes que se formam a partir dessas trocas é recorrente na literatura especializada. Há certa tradição na Ciência Política brasileira que se dedica a compreender os processos que associam mandatários e candidatos a cargos eletivos proporcionais a políticos que ocupam cargos no Executivo e ao eleitorado. A literatura especializada reafirma, tanto em trabalhos de cunho mais teórico quanto em análises empíricas, a constante preocupação dos políticos com a manutenção dos postos de poder e de autoridade alcançados, o que significa que a (re)eleição estaria no centro das preocupa- 
ções dos mandatos eletivos. Os determinantes do êxito nessa empreitada são tema controverso entre os especialistas (Santos 1997; Amorim Neto \& Santos 2001; Pereira \& Rennó 2001). É possível afirmar, contudo, que um dos principais instrumentos utilizados para a manutenção de seus postos são seus recursos de autoridade. Esses recursos de autoridade dizem respeito à sua parcela de poder de barganha ou troca no processo decisório, sobre toda sorte de benefícios públicos: alocação de recursos financeiros, legislação, apoio político, entre outros. Seja a partir de trocas políticas entre deputados de partidos distintos ou do mesmo partido, seja a partir de trocas entre Legislativo e Executivo, entre instâncias federativas ou entre representantes e representados, esses recursos de autoridade servirão como instrumento de manutenção de suas redes de relações. Trabalhos de análise empírica vêm sendo realizados procurando operar com o conceito de rede, onde as trocas políticas constituem os elos de uma cadeia (Fischer 1997; Marques 2000; 2003; 2010).

Alguns trabalhos têm se reportado aos nexos que relacionam comportamento parlamentar, relações Executivo-Legislativo e a competição eleitoral, nexos apresentados sob a alcunha de "conexão eleitoral" (Pereira 2002; Cervi 2009). Alguns estudos consagrados sobre comportamento legislativo, no entanto, concentram-se na Câmara dos Deputados e assembleias legislativas (Figueiredo \& Limongi 1999; Pereira \& Rennó 2001; Santos 2001). Pouco se produz sobre as casas legislativas municipais (Andrade 1998; Kuschnir 2000a; 2000b; 2007; D’Ávila Filho 2008). Em parte, essa lacuna deve-se às dificuldades dos vereadores em produzir uma legislação local significativa, diante dos constrangimentos impostos pelas Constituições Federal e Estadual, restando pouca margem para a criatividade do vereador, como será visto mais adiante. Mas, como veremos abaixo, os vereadores têm outras possibilidades de atuação.

A atual Constituição garante aos municípios a capacidade de se auto-organizar, a partir de sua Lei Orgânica, tendo também autonomia legislativa que verse sobre suas peculiaridades: autogovernar-se, por meio da eleição dos prefeitos e vereadores; autoadministrar-se por meio da gestão de seus negócios, sempre em consonância com as Constituições Federal e Estadual; e autonomia financeira, que permite participar nas receitas estaduais e federais e insere novos tributos em sua competência. Cabe ressaltar que autonomia não se confunde com soberania, visto que esta última refere-se ao poder irrestrito de dirigirse conforme suas prerrogativas, sem interferências externas. Já a autonomia diz respeito a uma liberdade limitada, isto é, compreende o poder de decidir, legislar, organizar e administrar com restrições. Percebe-se, portanto, que apesar de garantir-se a autonomia dos municípios, estes devem observar os princípios constitucionais da República Federativa do Brasil e do estado ao qual pertencem.

Além dos obstáculos constitucionais, os custos de elaboração, negociação e tramitação de um projeto de lei são maiores do que os de outros dispositivos legislativos, como as indicações. As indicações de obras ou serviços que são realizados pelo poder Executivo parecem mais vantajosas em função da rapidez dos resultados e da facilidade de reivindicar o crédito pela autoria da proposição se comparadas aos projetos de lei, por exemplo, que precisam obter o apoio da maioria dos legisladores e correm o risco de serem vetados pelo poder

${ }^{5}$ Trata-se daquilo que os autores clássicos da conexão eleitoral denominam de credit claming. Ou seja, a possibilidade de reivindi-
Executivo $^{5}$. Diante dessas dificuldades, outros serão os mecanismos por meio dos quais os vereadores poderão conquistar a preferência do eleitor a partir de sua atividade no Legislativo. As funções da Câmara não se resumem apenas ao processo de produção de legislação. Uma importante descoberta da pesquisa 
cação do crédito pela ação realizada. realizada em 2002 (D’Ávila Filho, Jorge \& Alves 2004) foi a percepção de que indicações, comumente vistas como pouco relevantes por alguns cientistas políticos e a imprensa de um modo geral, podem ser instrumentos de costura de redes políticas, sendo, por isso, importante a sua análise. Essas nomenclaturas variam de município para município, mas dizem respeito a um conjunto de pedidos dos vereadores ao prefeito. Pedidos esses que versam sobre obras em determinada localidade ou sobre a promoção de certos benefícios para segmentos específicos da comunidade. Tomando o parlamentar como um ator racional que ocupa boa parte de sua ação política no intuito de garantir a manutenção ou ampliação de seus postos de poder, torna-se razoável considerar, para efeitos de análise, uma produção que ocupa parte significativa de sua atividade.

\section{A atividade legislativa municipal}

\author{
${ }^{6}$ Além dessas quatro funções, os \\ regimentos internos dos municí- \\ pios estudados anteriormente \\ mencionam ainda a função de \\ controle político-administrativo \\ (D’Ávila Filho, Jorge \& Alves \\ 2004).
}

${ }^{7} \mathrm{O}$ ponto aparece de formas distintas nos regimentos internos dos diferentes municípios analisados (idem)

${ }^{8}$ A análise da produção legislativa não nos permite verificar o quanto a Câmara Municipal do Rio de Janeiro exerceu, de fato, as funções mencionadas. Este, porém, não é o objetivo deste trabalho.

\footnotetext{
${ }^{9}$ É o que sugere uma análise feita por pesquisadores da PUC-Rio no sítio da Câmara Municipal do Rio de Janeiro em meados da última década. Ver D’Ávila Filho (2005).
}

A Câmara Municipal possui quatro funções: fiscalizar, legislar, julgar e administrar ${ }^{6}$. No que diz respeito à função fiscalizadora, a Câmara Municipal deve acompanhar o poder Executivo quanto às questões de ações administrativas, fiscalizando a execução das matérias orçamentárias, contábeis, operacionais e patrimoniais. A função de legislar refere-se à competência da Câmara de elaborar normas jurídicas (leis orgânicas, ordinárias e orçamentárias) e regular o processo legislativo (Regimento Interno). Já a função de julgar ocorre somente quando acontecem infrações político-administrativas executadas pelo prefeito, vice-prefeito ou vereador ${ }^{7}$. Por fim, outra atribuição que compete ao Legislativo é a de administrar, que consiste na operacionalidade e organização interna da Câmara Municipal ${ }^{8}$.

Outra função, sugerida pela pesquisa, corresponde àquela que Ackel Filho (1992, p. 85) denomina de "participativa" Os legisladores, segundo Ackel, participam da ação administrativa encaminhando moções, requerimentos e indicações. É essa última função que pretendemos destacar e que estamos aqui chamando de "intermediação de interesses paroquiais", em seu sentido estrito. É comum que parlamentares encampem reivindicações e agendas pontuais de grupos identitários, segmentos sociais ou organizações funcionais. Diversamente, aqui, os interesses devem ser entendidos como "paroquiais", ou seja, os de um pequeno grupo cujo interesse comum pode ser de ordem geográfica, formado, portanto, em bases territoriais: uma localidade, que pode abranger um bairro ou parte dele ou, ainda, um conjunto de bairros. A referência a uma base eleitoral territorializada é o que mais aparece nos discursos dos vereadores $^{9}$. Nela, os vereadores parecem constituir-se em ouvidores "públicos".

Constitucionalmente, o parlamentar representa interesses sociais pressupostos, expressos nas quatro funções acima delineadas. Desse modo, fiscalizar, legislar, julgar e acompanhar a administração pública do poder Executivo são atividades desenvolvidas pelos eleitos em nome de toda a sociedade. Segundo a perspectiva pluralista, o parlamento exerce uma função de intermediação dos diversos interesses sociais junto ao Estado. Sem deixar de reconhecer essa perspectiva - ainda que sem discutir seu mérito - queremos chamar a atenção para a singularidade da atividade legislativa local referente às indicações. Enquanto nas quatro funções citadas os interesses são pressupostos genéricos, difusos e podem estar distantes da vida do cidadão, a atividade não estatutária de "ouvidor público" é pós-fixada, específica, concentrada e diretamente ligada ao dia a dia dos indivíduos afetados por ela. Pós-fixada, na medida em que é resultado da interação constante entre produção de demandas e representação 
política. Enquanto as primeiras são funções constitucionais normativas, mediadas pela dinâmica política, a segunda, "intermediação de interesses paroquiais", é resultado do jogo político, de interesses e de estratégias, ainda que previstas no Regimento Interno das câmaras.

Mais adiante, quando discutiremos a produção legislativa ordinária no município do Rio de Janeiro, mostraremos que a função de "intermediação de interesses paroquiais" (assessoramento ou participativa) é bastante significativa, visto que foram encontrados elevados números de indicações na base de dados fornecida pela Câmara Municipal, referente à produção legislativa 2001-2004.

Embora o trabalho do vereador não se reduza somente à atividade legislativa, dentre as funções de um parlamentar, esta é uma das mais importantes, segundo a literatura especializada. $\mathrm{O}$ processo legislativo compreende uma variedade de atividades reguladas e institucionalizadas cujo resultado final é a sanção ou rejeição, pelos vereadores ou pelo prefeito, de um projeto de lei. Sendo assim, não é sem razão que a literatura especializada concentra sua atenção nessa dimensão, procedimentos e resultados da função legislativa. Nosso intuito, no entanto, é sugerir que para o entendimento da competição política eleitoral e da dinâmica política local, onde o ato de legislar ocupa reduzido espaço na agenda política do vereador, como veremos em seguida, é preciso voltar o olhar para outro aspecto da atividade parlamentar: a "intermediação de interesses paroquiais", representada no ato parlamentar das indicações.

\section{A produção legislativa no município do Rio de Janeiro}

O objetivo desta seção é mostrar o que produziram os vereadores entre 2001 e 2004. O Gráfico 1 sintetiza as informações sobre a produção legislativa encontrada no município do Rio de Janeiro nesse período. Destacamos que $57 \%$ correspondem a moções, $29 \%$ a indicações e $4 \%$ a projetos de lei. O percentual de indicações encontrado no município do Rio de Janeiro, portanto,

Gráfico 1 - Produção legislativa ordinária da Câmara Municipal do Rio de Janeiro (2001-2004)

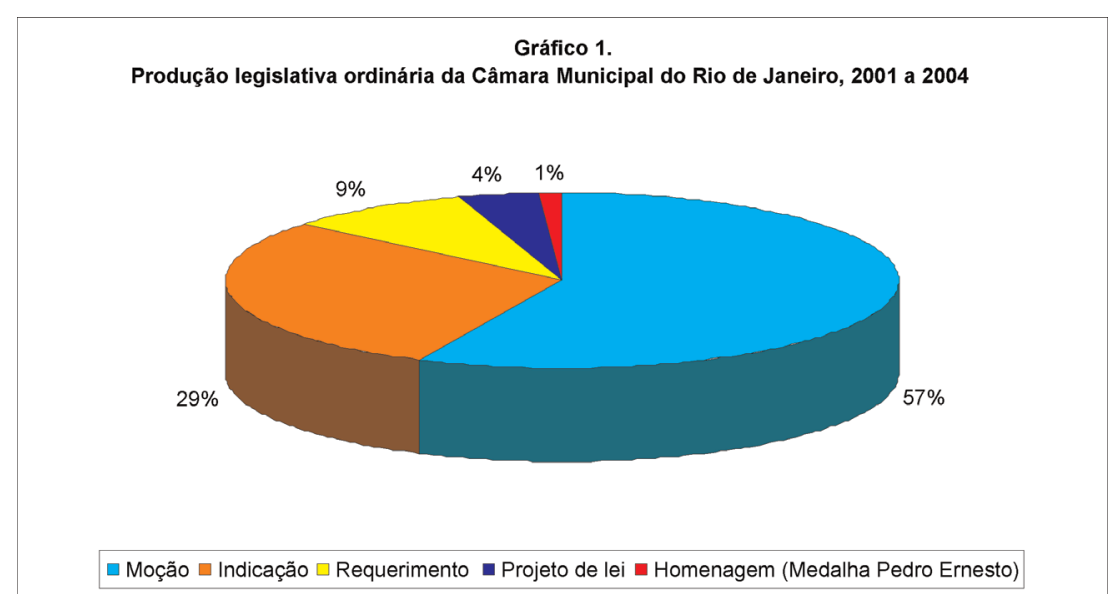

FONTE: Banco de dados fornecido pela Câmara Municipal do Rio de Janeiro. Nota: N $=70.590$ iniciativas 
${ }^{10}$ Sobre as competências do município, ver o Art. 30 da Constituição Federal. só é menor que o de moções. Como seria de se esperar, em função da complexidade anteriormente mencionada, os projetos de lei encontram-se em menor número.

Por que os vereadores do Rio de Janeiro, como os de outros municípios fluminenses, exercem pouco a sua prerrogativa de legislar? Antes de tudo, devemos esclarecer que provavelmente essa não é uma característica exclusiva dos municípios fluminenses. Como já dissemos anteriormente, uma hipótese plausível é que as atribuições dos poderes locais, Executivo e Legislativo, são muito limitadas, restando muito poucos assuntos sobre os quais os municípios podem e devem exercer regulação. Além disso, os custos de transação e o tempo requerido para a tramitação de um projeto de lei são muito maiores (D'Ávila Filho 2008) ${ }^{10}$. O que o Gráfico 1 mostra é que (seja em função das limitações impostas pela lei, pelos custos de transação ou seja pela possibilidade de obtenção de crédito rápido pela autoria da proposição) há a escolha, por parte significativa (como veremos adiante) dos vereadores, de outro tipo de atividade frequentemente considerada pelos meios midiáticos como menos relevante: a de ser o intermediário entre o poder Executivo e a comunidade. Em outras palavras, a de ser um intermediário entre os interesses dos demandantes de serviços e benefícios públicos e os agentes públicos dotados de meios legais e administrativos para atendê-los. No Gráfico 1, acima, o exercício dessa função aparece na apresentação de indicações e requerimentos. Em relação às homenagens e moções, embora possam igualmente proporcionar-nos instrumentos para identificar as redes eleitorais dos mandatários, possuem natureza distinta dos primeiros. Sua análise e investigação exigem métodos diferenciados. Ainda que sugiram estudos instigantes, neste trabalho concentramonos exclusivamente nas indicações.

\section{Intermediação de "interesses paroquiais": as indicações}

A análise das indicações parte de um modelo formado por uma tríade de atores: prefeito, vereadores e eleitorado, em um contexto de competição político-eleitoral. Uma tríade formada por trocas políticas assimétricas de dois níveis. Uma entre o poder Executivo e o poder Legislativo, outra entre candidatos ou mandatários de cargos legislativos e seus eleitores potenciais. Nesse modelo, o vereador pretende justamente aparecer como mediador entre os dois níveis de troca. Vem dessa premissa o papel, por nós sugerido, do vereador como "ouvidor" no processo de "intermediação de interesses paroquiais".

O modelo parte do princípio de que esses atores racionais procuram maximizar seus ganhos constrangidos pelas regras do jogo democrático. Sendo assim, ainda que assimétricas, as trocas envolvidas nessas interações podem produzir efeitos benéficos para todos os envolvidos, mesmo que seus resultados sejam diferenciados, seja aos olhos dos atores, seja da perspectiva do observador (D'Ávila Filho 2000; D’Ávila Filho, Alves \& Jorge 2002; Bahia 2003). Uma externalidade positiva agregada dessas interações poderia ser o reforço das instituições democráticas, a partir do exercício da representação política, e o sentimento de eficiência dele derivado, quando todos os atores veem-se satisfeitos com o produto dessas trocas. A correlação estabelecida nesse modelo, entre as trocas Executivo-Legislativo e entre as trocas eleitorrepresentante é o que podemos chamar de "conexão eleitoral local", em alusão

${ }^{11}$ Sabemos que a noção de conexão eleitoral vai além disso. Ela aos estudos realizados pela literatura mais recente (Pereira \& Rennó 2007) ${ }^{11}$. A perspectiva de analisar os mecanismos de troca política articulados aos te- 
implica considerar, adicionalmente no "cálculo", a origem dos votos do parlamentar em questão. Trata-se, portanto, da relação entre a origem dos votos e a atuação do parlamentar. Ela implica considerar não apenas o "paroquialismo" do legislador, mas a relação entre a geografia do voto e o destino dos benefícios políticos que resultam da atuação do parlamentar. Embora não seja o foco desta pesquisa, por enquanto, será instigante "cruzar" nossos dados sobre a produção de indicações com a origem geográfica dos votos de cada vereador. Aí sim se poderia verificar a "conexão eleitoral" propriamente dita, tal como apresentada pela literatura especializada, ou seja, a relação entre a origem dos votos e a alocação de recursos, benefícios ou serviços por parte do parlamentar. Dessa forma, poderíamos responder melhor à pergunta sobre se o instrumento indicações gera efeitos positivos para o vereador, comprováveis em termos de retorno eleitoral, aumentando as chances de reeleição. Em que pese esse desdobramento futuro, previsto na pesquisa em andamento, acreditamos que a dedicação de parte significativa dos vereadores ao uso desse dispositivo legislativo já nos permite, aceitas as premissas da preocupação precípua com a conquista e a manutenção de seus mandatos, afirmar que as indicações são um instrumento importante para a "conexão eleitoral local". Uma pesquisa que demonstrasse, em direção contrária à nossa proposição, baixa correlação entre o uso das indicações e o rendimento eleitoral, sugeriria baixa capacidade de racionalização, direcionada à maximização de oportunidades, por parte do vereador que mobiliza o instrumento. A premissa da pesquisa é inversa. Os vereadores acreditam que o dispositivo trazlhes ganhos na formação de sua rede de apoio político e possuem conhecimento sobre os mecanismos que interferem sobre a preferência eleitoral de seu público alvo.

${ }^{12}$ Segundo Pereira e Rennó (2007), a conexão eleitoral forma-se a partir de um poder Executivo que concentra recursos políticos e de poder, líderes partidários com capacidade de negociar mas da governabilidade ou da composição da representação não é nova na reflexão política. Foi expressa de diversas maneiras em contextos distintos pelo pensamento clássico e contemporâneo, seja de matriz realista seja pluralista, mas que ganham um esforço sistematizado de análise empírica em trabalhos recentes (Santos 2003; Figueiredo \& Limongi 2008) ${ }^{12}$.

A hipótese que orienta a análise a seguir é a de que o instrumento legislativo representado pelas indicações pode ser uma importante chave de entendimento das trocas contidas na tríade mencionada em nível local, municipal. Tomemos, como ponto de partida, a importância das indicações para a competição eleitoral, isto é, como opção estratégica para o vereador que pretende se reeleger ou eleger-se para outro cargo público.

Na relação entre o Executivo, o Legislativo e os eleitores, o primeiro precisa do segundo para governar. Por isso, o primeiro precisa obter o apoio do segundo ou ao menos de sua maioria. Uma possibilidade aqui apresentada é que, na política municipal, uma das formas de conquistar esse apoio é atender às indicações dos vereadores. Por outro lado, as propostas dos vereadores precisam do poder Executivo para sua efetivação, sua execução. Para além das negociações que esse arranjo engendra (a partir muito mais do jogo político do que das atribuições normativas que constituem os dois poderes), o cenário desenhado possibilita a construção de uma rede eleitoral. Rede que envolve o terceiro ator, o eleitorado. A interferência do vereador na consecução de suas demandas poderia denotar não só a preocupação do representante para com as "necessidades" de seus representados como, também, sua capacidade de obter ação efetiva do Executivo, ou seja, sua eficácia.

Em suma, sugerimos um modelo de conexão eleitoral local formado por uma tríade de atores (prefeito, vereadores e eleitorado) que, em um contexto de competição político-eleitoral, realizam trocas políticas assimétricas de dois níveis. Conforme mostra o Diagrama 1, no primeiro nível, a troca ocorre entre o Executivo e o Legislativo; no segundo nível, ocorre entre vereadores (em

Diagrama 1 - Modelo de conexão eleitoral local
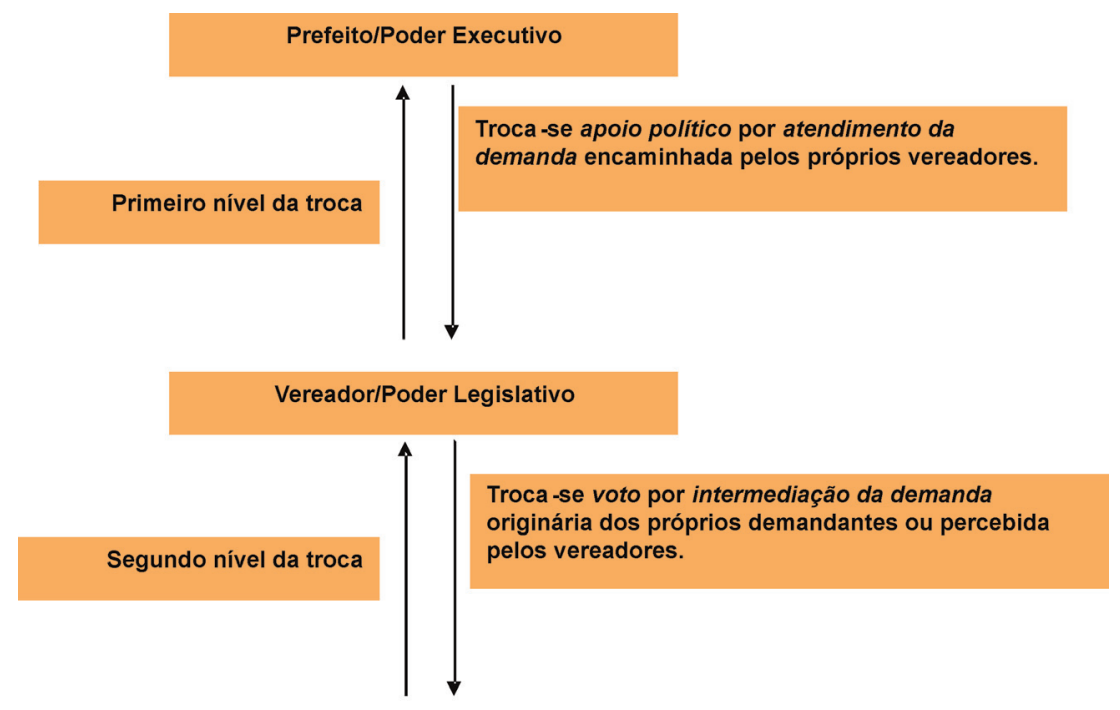

Eleitorado

FONTE: Os autores 
esses recursos e parlamentares subordinados às alianças partidárias, interessados na obtenção de recursos para a produção de políticas distributivas locais, procurando obter apoio político em âmbito municipal e o voto pragmático do eleitor interessado na resolução de seus problemas paroquiais. Figueiredo e Limongi (2008) por sua vez argumentam que os recursos controlados pelos líderes dos partidos, que têm poder de barganha com o Executivo, impelem os parlamentares a um comportamento mais partidário. Estes tenderiam a votar com a liderança partidária, a partir da possibilidade de auferir certos benefícios negociados com o Executivo, que por sua vez concentra os recursos necessários à produção da reeleição parlamentar.

\footnotetext{
${ }^{13}$ Há um caso sugestivo encontrado em Mangaratiba (RJ) que serve como uma ilustração desse ponto. Reproduzimos os termos da Ata da Câmara Municipal de Mangaratiba, de 17 de março de 1994, na qual ocorre uma disputa pela paternidade de uma indicação: “[...] Aparteando, o Vereador Eduardo sugeriu que o Vereador Leonardo retire a indicação de n. ${ }^{\circ} 33 / 94$, já que se encontra registrada, nesta Casa, a solicitação referente ao assunto, feita pela Vereadora Maria das Graças. [...] o Vereador Leonardo, reportando-se a fala da Vereadora Maria, esclareceu que vem pedindo o conserto da estrada da Serra do Piloto, já há cerca de quatro meses [...]".
}

busca da (re)eleição) e seus eleitores potenciais. Nesse modelo, o vereador aparece como mediador entre os dois níveis de troca.

As indicações sugerem um esforço do representante em atender às expectativas daqueles que o elegeram ou podem vir a eleger. Com as indicações, o vereador cumpre o papel que lhe foi designado pelos que o elegeram, que é o de representar e defender os interesses destes perante os demais vereadores e o poder Executivo. Dessa forma, o eleito cumpre a promessa feita durante a campanha eleitoral, assinalando para os que o elegeram que não os abandonou. Para os que não o elegeram, assinala que se preocupa com a comunidade onde vivem, independentemente da sua opção eleitoral.

Uma demanda, entretanto, não é necessariamente produto da percepção que a própria comunidade tem de um problema comum. Não havendo uma demanda da qual o parlamentar possa apropriar-se, a fim de gerar ou aumentar seu capital político, caberá a ele, como parte interessada em exercer sua representação e levar seus créditos, detectar ou apresentar problemas locais para os quais ele possui alguma solução e mobilizá-la com o intuito de transformá-los em demandas a serem atendidas pelo poder Executivo. Nesse caso, a indicação pode ser entendida como manufatura da representação e não emanação de uma "vontade do povo", embora encontre receptividade entre os beneficiados. Ela é produto e não motor do jogo político, em clara alusão a Schumpeter (1984). Em ambos os casos, no entanto, se todos cooperarem, as partes da tríade terminam por satisfeitas.

Entretanto, para que essa cadeia se realize, o vereador precisa não só formular uma indicação como, e isso é fundamental, garantir seus "direitos autorais" sobre esse capital político. Na pesquisa realizada em 2002, encontramos evidências da importância atribuída pelos vereadores à confirmação da referida autoria (credit claming). Os vereadores competem pela paternidade da indicação ${ }^{13}$. O número do protocolo da indicação é a segurança da "propriedade intelectual" desse capital político, que precisa ser protegido. No debate, a "primeira indicação" é a que vale como capital político para fins eleitorais e prova do exercício da representação, mesmo que em um segundo momento outro vereador tenha feito a mesma indicação.

Um importante aspecto na competição política, contudo, é a comunicação ao eleitor dos feitos do parlamentar, se possível, face a face. Se, por um lado, o êxito na competição eleitoral pressupõe atender a, se não todas, pelo menos algumas expectativas dos eleitores, por outro, requer que se faça uma comunicação a fim de vincular a satisfação de uma expectativa ou o atendimento de um interesse a um nome em particular.

A execução da indicação dependerá de negociações e das trocas entre o prefeito e o vereador proponente, não sendo possível predizer se este obterá sucesso. Na pior das alternativas, o parlamentar, ao menos, tem a prova, a partir do registro de autoria, do esforço despendido em nome de "sua comunidade". No melhor cenário, o vereador comprova sua intermediação perante a obra executada.

A execução de uma indicação, como dito, dependerá de um conjunto de fatores que podem envolver negociação, interesses mútuos, conveniências e cálculos. Envolve as capacidades mútuas de produzir cooperação entre as partes. Os determinantes da cooperação ainda não podem ser precisados pelos elementos empíricos que possuímos, mas há evidências de que, ao menos nesse aspecto, a dinâmica municipal não é muito diferente do que se passa na 
esfera federal. A pesquisa realizada anteriormente permitiu-nos concluir que o crescimento da base de apoio do governo na Câmara, constituindo maioria, tende a facilitar a gestão de governo a tal ponto que as solicitações encaminhadas pela situação passam a não contar com a mesma acuidade do prefeito (D’Ávila Filho, Jorge \& Alves 2004).

Se para o prefeito a adesão da oposição à sua base parlamentar garante-lhe mais apoio no Legislativo, o fato transforma-se em um problema para os vereadores da situação, pois assim perdem o diferencial que os distingue de seus oponentes partidários: o acesso ao Executivo, o atendimento da indicação ou equivalente. Na medida em que os vereadores migram para a base de apoio do governo, a utilidade esperada do apoio ao poder Executivo diminui, pois aumenta a competição pelos recursos de que este dispõe para distribuição entre os seus aliados. Um elemento de troca do vereador com o Executivo é o seu apoio. Ainda que o recado contido nessas linhas possa não ter consequências práticas, em função da grande dependência dos mandatários proporcionais com relação ao Executivo, há aqui uma sinalização clara da utilidade esperada na troca (D'Ávila Filho 2008). O prefeito não é indiferente a esse tipo de sinalização, como sugerimos em nosso trabalho anterior (D'Ávila Filho, Jorge \& Alves 2004).

$\mathrm{O}$ atendimento das indicações ou a inclusão delas no projeto de governo do prefeito é, por um lado, um sinal de prestígio do vereador junto ao prefeito e, por outro, denota uma atuação parlamentar competente, eficaz. Isso não significa apenas um ganho simbólico, mas também um trunfo eleitoral para o vereador que quer se reeleger, já que poderá usá-lo para atingir três objetivos perseguidos por todo candidato que já detém um mandato parlamentar: (1) Preservar seus eleitores, pois as indicações servem para atender a uma necessidade dos que, por algum motivo, já votaram e continuarão votando no parlamentar (eleitores efetivos ou de fato); (2) Conquistar novos eleitores, pois as indicações servem para assinalar para o eleitor em potencial que pode confiar no candidato, já que ele teve um desempenho legislativo produtivo e agiu para atender às expectativas dos que votaram nele na última eleição; (3) Tirar votos do concorrente. Há, aqui, dois tipos de concorrente: (3.1) O que já possui um mandato, pois mostra que sua atuação parlamentar foi mais produtiva e eficiente do que a do seu concorrente; (3.2) O novato, isto é, o que disputa o primeiro mandato, pois o seu currículo torna-o merecedor de um mandato.

Parte-se da premissa de que é racional o ator político querer conquistar e manter o poder, seja qual for a sua finalidade. Para efeito da análise aqui empreendida suas motivações pouco importam. Desde uma vereança, passando por cargos no governo até a Presidência da República, o importante é controlar algum recurso de poder político e decisório. A perspectiva interpretativa com a qual estamos operando é a de que o eleitor mede a eficiência parlamentar local não apenas em termos de sua produção legislativa, mas, e talvez principalmente, em termos de "melhorias" obtidas para o local onde ele vive: a rua, o bairro ou o município. Todavia, quanto mais distante estiver a "melhoria" do local onde o eleitor efetivamente vive, menos este a perceberá como um bene-

${ }^{14}$ Para alguns autores, como Baquero (1997), os eleitores estariam adotando um comportamento pragmático. fício para $\mathrm{si}^{14}$.

Convém fazer um comentário sobre os objetivos elencados. Os objetivos 1 e 2 pressupõem que o eleitor fará uma avaliação da atuação isolada do parlamentar. Já o objetivo 3 pressupõe que, durante a eleição, o eleitor avaliará a atuação do parlamentar em relação à dos demais e comparar o currículo deste com o dos demais candidatos. Portanto, a indicação é um dos meios disponí- 
veis e utilizados pelos vereadores para, durante o cumprimento do seu mandato, preservar os vínculos que estes estabeleceram durante a campanha eleitoral com os eleitores, ou para estabelecer novos vínculos. Em relação aos "novatos", a indicação dá ao detentor de um mandato uma vantagem de saída, já que quem está concorrendo a um mandato pela primeira vez não pode lançar mão desse recurso. Em outras palavras, a vantagem de estabelecer e manter redes de trocas políticas verticais, nas quais se trocam recursos de autoridade por apoio.

\section{Padrões de emissão de indicações pelos vereadores}

A Tabela 1 mostra que a quantidade de indicações emitidas cresce até a primeira metade do mandato, correspondendo a $62,3 \%$ do total, decrescendo a partir daí. Observe-se que o total de indicações emitidas no último ano corresponde a apenas $49,2 \%$ da quantidade de indicações registrada no primeiro ano. Submetido ao teste $\chi^{2}$ de aderência - considerando-se esse conjunto uma amostra do processo mais amplo e dinâmico de geração de indicações - rejeitou-se $(\mathrm{p}=0,0)$ a hipótese de a distribuição de probabilidades da emissão anual de indicações ser uniforme.

Não sabemos, ainda, se o comportamento dos vereadores cariocas observado na Legislatura 2001-2004 (o de formular a maioria das indicações na primeira metade dos seus mandatos) é padrão. Se for, há pelo menos três motivos não excludentes e plausíveis que, quando combinados, podem explicar esse comportamento: (1) Saldar "dívidas de campanha" com o eleitor. É plausível supor que, tanto ao longo da campanha eleitoral quanto no início do cumprimento do mandato legislativo, aumente o número de solicitações feitas ao candidato e, posteriormente, vereador. Este prontifica-se a atendê-las imediatamente com o intuito de manter a conexão estabelecida com o cidadão, o que lhe permitirá preservar e/ou ampliar o seu eleitorado; (2) O tempo para o poder Executivo responder às indicações tende a desestimular o vereador a apresentá-las nos meses que antecedem a eleição; (3) é plausível supor que algumas restrições impostas pela legislação também desestimulem o vereador a apresentar, nos dois últimos anos de seu mandato, indicações destinadas à realização de investimentos, principalmente aqueles cuja conclusão só ocorreria menos de três meses antes do dia das eleições. Há pelo menos duas restrições: (3.1) o Artigo n. 73 da Lei Eleitoral n. 9.504/97 e a Resolução do Tribunal Superior Eleitoral (TSE) n. 20.988/02 desautorizam, nos três meses que antecedem a eleição, publicidade institucional dos atos, programas, obras, serviços e campanhas dos órgãos públicos, ou das respectivas entidades da administração indireta, salvo em caso de grave e urgente necessidade pública. Nesse caso, o vereador é desestimulado porque sabe que não poderá ter o seu

Tabela 1 - Distribuição de frequências da emissão anual de indicações por ano

\begin{tabular}{lccc}
\hline Ano & N & \multicolumn{2}{c}{ Indicações } \\
& \% & \% acumulado \\
\hline 2001 & 6400 & 30,3 & 30,3 \\
2002 & 6748 & 32,0 & 62,3 \\
2003 & 4814 & 22,8 & 85,1 \\
2004 & 3151 & 14,9 & 100 \\
S. I. & 4 & 0 & 100 \\
Total & 21117 & 100 & - \\
\hline
\end{tabular}

FONTE: Câmara Municipal do Rio de Janeiro.Nota: S. I. - sem informação. 
${ }^{15}$ Proibição ao titular de poder ou órgão de contrair obrigação de despesa, nos dois últimos quadrimestres do seu mandato, que não possa ser cumprida integralmente dentro dele, ou que tenha parcelas a serem pagas no exercício seguinte sem que haja suficiente disponibilidade de caixa (Art. 42 da LRF, de $1^{\circ}$ de maio de 2002).

${ }^{16}$ Estudos recentes mostram uma tendência dos parlamentares de utilizar os primeiros anos do mandato para "pagar dívidas" eleitorais, priorizando o atendimento de demandas localizadas dos eleitores, e os últimos para "costurar" acordos e apoios político-partidários (institucionais) com vistas à viabilização e financiamento da campanha nas eleições seguintes. nome explicitamente associado à realização de determinada obra, sobretudo aquelas de grande vulto; (3.2) O Artigo n. 42 da Lei de Responsabilidade Fiscal (LRF), de $1^{\circ}$ de maio de 2002, proíbe o representante (prefeito e vereadores) de contrair obrigação de despesa nos oito meses que antecedem o fim do seu mandato ${ }^{15}$. Nesse caso, o vereador é desestimulado porque sabe que não será atendido pelo poder Executivo se a indicação exigir que o prefeito contraia obrigação de despesa no período referido.

As categorias de análise do conteúdo das indicações foram construídas agrupando-se em "melhoria" as indicações destinadas a investimentos em serviços básicos e de infraestrutura; em "manutenção", aquelas direcionadas à conservação desses serviços e, em "outros/imaterial", as demais indicações destinadas a pedidos de fiscalização, perícia técnica entre outros. A Tabela 2 mostra que as 21.117 indicações distribuem-se entre melhoria $(56,3 \%)$ e manutenção $(41,7 \%)$, cabendo a outras/imateriais apenas $1,8 \%$ do total.

Embora não seja o foco desta pesquisa, seria interessante "cruzar" esses dados com a origem geográfica dos votos de cada vereador. Aí sim se poderia verificar a "conexão eleitoral", ou seja, a relação entre origem dos votos e a alocação de recursos/benefícios/serviços por parte do parlamentar.

Diante das restrições da lei vistas acima, cabe saber se os vereadores cariocas observados na Legislatura 2001-2004 mantiveram, em proporções iguais, as indicações destinadas a "melhoria", "manutenção" e "outros/imaterial" ao longo de todo o período. A Tabela 3, a seguir, mostra que não. O teste $\chi^{2}$ aplicado aos dados da tabela indica a rejeição $(p=0,0)$ da hipótese de independência como uma tendência a ser observada no processo mais amplo de geração de indicações, concluindo-se que os percentuais de emissão de indicações segundo a categoria efetivamente dependem do ano de emissão, ou seja, variam segundo este último. Observe-se, na Tabela 3, que o percentual de indicações para investimentos (melhoria) cai progressivamente com o andamento da legislatura. A queda mais acentuada é do segundo para o terceiro ano de mandato $(13,1 \%)$, mas a ocorrida entre o terceiro e o quarto anos de mandato $(10,6 \%)$ também foi maior do que a registrada entre o primeiro e o segundo anos de mandato (apenas 6,2\%). O que isso nos sugere? Sugere que os vereadores podem ter condicionado a apresentação de indicações relativas a investimentos às restrições impostas pela legislação vigente e ao tempo que julgam que o poder Executivo vai levar para atendê-las. Em outras palavras, essa estratégia eleitoral perde atratividade à medida que vai se aproximando o dia da eleição, o que denota uma racionalidade na atuação do vereador ${ }^{16}$. Alguns estudos também apontam para uma tendência de utilizar os primeiros anos do mandato para "pagar dívidas" eleitorais, priorizando o atendimento de demandas localizadas dos eleitores, e os últimos para costurar" acordos e apoios político-partidários (institucionais) com vistas à viabilização e financiamento da campanha nas eleições seguintes (especialmente os estudos de Douglas Arnold, em relação aos deputados estadunidenses).

Tabela 2 - Distribuição das indicações por categoria de análise

\begin{tabular}{lc}
\hline Categoria & \% de indicações \\
\hline Melhoria & 56,3 \\
Manutenção & 41,7 \\
Outros/Imaterial & 1,8 \\
S. I. & 0,2 \\
Total & 100 \\
\hline
\end{tabular}

FONTE: Câmara Municipal do Rio de Janeiro.Nota: S. I. - sem informação. 
${ }^{17} \mathrm{O}$ IDH dos bairros cariocas estão disponíveis no site do PNUD. Ver: http://www.pnud.org.br/pdf/ Tabela\%206.2.22\%20IDH\% 20bairro\%2091_00-15_12_03. xls. Acesso em: 24.jan.2014.
Tabela 3 - Distribuição das indicações por categoria, segundo o ano (\%)

\begin{tabular}{lccccc}
\hline Ano & Melhoria & \multicolumn{2}{c}{ Categoria de análise } & \multicolumn{2}{c}{ Total } \\
& Manutenção & $\begin{array}{c}\text { Outros } \\
\text { (Imaterial) }\end{array}$ & S. I. & \\
\hline 2001 & 62,7 & 34,4 & 2,8 & 0,1 & $100(\mathrm{~N}=6400)$ \\
2002 & 58,8 & 40 & 1 & 0,2 & $100(\mathrm{~N}=6748)$ \\
2003 & 51,1 & 46,9 & 1,8 & 0,1 & $100(\mathrm{~N}=4814)$ \\
2004 & 45,7 & 52,4 & 1,5 & 0,3 & $100(\mathrm{~N}=3151)$ \\
S. I. & 100 & - & - & - & $100(\mathrm{~N}=4)$ \\
Total & 56,3 & 41,7 & 1,8 & 0,2 & $100(\mathrm{~N}=21.117)$ \\
\hline
\end{tabular}

FONTE: Câmara Municipal do Rio de Janeiro.Nota: S. I. - sem informação.

O município do Rio de Janeiro está dividido em quatro zonas geográficas: Centro, Norte, Oeste e Sul. Essa última é a mais nobre e rica, nela situando-se os bairros com os maiores Índices de Desenvolvimento Humano (IDH) do município: Gávea $(0,970)$, Leblon $(0,967)$, Ipanema $(0,962)$, Lagoa $(0,959)$, por exemplo. A primeira zona (Centro) contém o centro administrativo, financeiro e histórico. As zonas Norte e Oeste, por sua vez, são áreas muito extensas e bastante heterogêneas, encontrando-se nelas tanto bairros com IDH altos como médios. Na Zona Oeste, a Barra da Tijuca ostenta um IDH de 0,959 enquanto Santa Cruz apresenta um IDH de 0,742. Na Zona Norte, o Maracanã e a Tijuca têm IDH de 0,944 e 0,926, respectivamente, muito superiores ao de Parada de Lucas, por exemplo, que tem IDH de 0,745. Bairros como Barra da Tijuca e Tijuca são habitados por pessoas pertencentes às classes alta e média-alta. A Zona Norte, por ser de urbanização mais antiga, pode ser caracterizada como uma área de transição entre as Zonas Sul e Oeste, tendo características de uma e de outra. Das quatro regiões, sem dúvida é a Oeste que tem a pior infraestrutura urbana ${ }^{17}$.

Os vereadores não distribuem homogeneamente as indicações pelas zonas geográficas do município do Rio de Janeiro. De acordo com a Tabela 4, as Zonas Norte e Oeste concentram a esmagadora maioria das indicações formuladas entre 2001 e 2004. As duas regiões mais pobres do município foram responsáveis por $97,3 \%$ das indicações. Às outras duas zonas geográficas da cidade, Sul e Centro, foram destinadas apenas 1,4\% e 0,4\% das indicações, respectivamente.

Os dados da Tabela 4 mostram que é nas zonas Norte e Oeste que as indicações são mais utilizadas pelo poder Legislativo como mediador dos interesses de regiões da cidade junto ao Executivo. Embora não possamos afirmar que isso seja um padrão, achamos plausível supor que as outras duas zonas, tanto pela composição social de seus habitantes quanto pela atenção que receberiam da mídia e sua importância econômica, fazem-se ouvir por outros mei-

Tabela 4 - Frequência das indicações por zona geográfica do município do Rio de Janeiro

\begin{tabular}{lccc}
\hline Zona & N & Indicações & \% cumulado \\
\hline Norte & 10984 & 52,1 & 52,1 \\
Oeste & 9550 & 45,2 & 97,3 \\
Sul & 293 & 1,4 & 98,7 \\
Centro & 91 & 0,4 & 99,1 \\
S. I. & 199 & 0,9 & 100 \\
Total & 21117 & 100 & - \\
\hline
\end{tabular}

FONTE: Câmara Municipal do Rio de Janeiro.Nota: S. I. - sem informação. 
Tabela 5 - Categorias de análise segundo a zona de destino da indicação (\%)

\begin{tabular}{lccccc}
\hline Zona & \multicolumn{3}{c}{ Categoria de Análise } & \multicolumn{2}{c}{ Total } \\
& Manutenção & Melhoria & $\begin{array}{c}\text { Outros } \\
\text { (Imaterial) }\end{array}$ & S. I. & \\
\hline Norte & $\mathbf{5 2 , 9}$ & 45,5 & 1,4 & 0,2 & $100(\mathrm{~N}=10984)$ \\
Oeste & 28,8 & $\mathbf{6 9 , 6}$ & 1,4 & 0,2 & $100(\mathrm{~N}=9.550)$ \\
Sul & $\mathbf{6 3 , 5}$ & 28,0 & 7,8 & 0,7 & $100(\mathrm{~N}=293)$ \\
Centro & 29,7 & $\mathbf{6 0 , 4}$ & 8,8 & 1,1 & $100(\mathrm{~N}=90)$ \\
S. I. & 17,6 & 49,2 & 32,2 & 1,0 & $100(\mathrm{~N}=193)$ \\
Total & 41,7 & 56,3 & 1,8 & 0,2 & $100(\mathrm{~N}=21117)$ \\
\hline
\end{tabular}

FONTE: Câmara Municipal do Rio de Janeiro.Nota: S. I. - sem informação.

os não institucionais. Por exemplo, é mais provável nas zonas Sul e Centro a comunicação direta com as secretarias ou mesmo com o próprio prefeito, por intermédio de recursos próprios ou de redes pessoais.

A Tabela 5, a seguir, mostra uma correspondência entre a natureza das indicações e a zona de sua destinação. $O$ teste $\chi^{2}$ aplicado indica a rejeição (p $=0,0$ ) da hipótese de independência entre as duas variáveis como uma tendência a ser observada no processo mais amplo de geração de indicações. Assim, a zona de destinação da indicação efetivamente diferencia a incidência das categorias.

$\mathrm{Na}$ Zona Oeste predominam as indicações destinadas a investimentos (69,6\%), enquanto na Zona Norte, a outra área concentradora de indicações, aquelas destinadas a manutenção $(52,9 \%)$ são majoritariamente contempladas. As zonas Norte e Sul, de melhor situação socioeconômica, receberam indicações que, proporcionalmente, contemplavam iniciativas de manutenção (respectivamente, $52,9 \%$ e $63,5 \%$ ) e, minoritariamente, de melhorias (investimentos).

De acordo com a Tabela 6, a seguir, oito temas foram responsáveis por mais de $90 \%(90,9 \%)$ das indicações voltadas para a Zona Norte, por mais de $80 \%$ das indicações formuladas para as zonas Oeste e Sul (respectivamente, $88 \%$ e $82,9 \%)$, e mais de $60 \%(66,7 \%)$ das indicações destinadas ao Centro.

As 21.117 indicações tiveram como temas principalmente vias públicas (26,5\%) e iluminação pública $(23,0 \%)$, seguidas de saneamento básico e arborização (ambas com 10,9\%). Nas zonas Oeste e Norte, ainda segundo a Tabela 6 , três temas foram responsáveis por mais de $60 \%$ das indicações. Na primeira, foram vias públicas $(30,8 \%)$, iluminação pública $(21,4 \%)$ e saneamento básico

Tabela 6 - Zona de destino das indicações segundo o tema (\%)

\begin{tabular}{lccccc}
\hline Tema & \multicolumn{2}{c}{ Zona } & \multicolumn{2}{c}{ Total } \\
\hline Vias públicas & Oeste & Norte & Sul & Centro & $\mathbf{2 6 , 5}$ \\
Iluminação pública & $\mathbf{3 0 , 8}$ & 23,6 & 14,7 & 7,8 & 23 \\
Saneamento básico & 21,4 & $\mathbf{2 4 , 6}$ & $\mathbf{2 6 , 3}$ & 10 & 10,9 \\
Arborização & 12,2 & 10,2 & 4,4 & 4,4 & 10,9 \\
Esporte/Lazer & 3,3 & 17,6 & 14 & 14,4 & 5,8 \\
Ordenação no trânsito & 7,6 & 4,2 & 10,2 & $\mathbf{1 5 , 6}$ & 4,9 \\
Programa governamental & 4,1 & 5,6 & 5,1 & 2,2 & 3,8 \\
Limpeza pública & 6,1 & 1,7 & 4,1 & 8,9 & 3 \\
Total & 2,5 & 3,4 & 4,1 & 3,3 & 88,8 \\
& 88 & 90,9 & 82,9 & 66,7 & $(\mathrm{~N}=21.117)$ \\
\hline
\end{tabular}

FONTE: Câmara Municipal do Rio de Janeiro.Nota: Incluídos os temas com os oito maiores percentuais de indicações por Zona. 
(12,2\%); na segunda, foram iluminação pública $(24,6 \%)$, vias públicas $(23,6 \%)$ e arborização $(17,6 \%)$. Esses percentuais, sobretudo os referentes aos temas vias públicas e iluminação pública, evidenciam algumas das carências, já bastante divulgadas pela imprensa e conhecidas do poder público, nessas regiões. Observe-se ainda que o tema saneamento básico aparece apenas em quarto lugar na Zona Norte, com o percentual de indicações de $10,2 \%$, o que não surpreende pois, como já referido, trata-se de uma região bastante heterogênea, integrada por bairros com padrões de urbanização e de infra-estrutura muito próximos ou muito distantes em relação aos da Zona Sul.

Os temas saneamento básico e vias públicas perdem força nas outras duas regiões, Sul e Centro. Na Zona Sul, quatro foram os temas que, juntos, perfizeram mais de $60 \%$ das indicações: iluminação pública $(26,3 \%)$, vias públicas $(14,7 \%)$, arborização $(14,0 \%)$ e esporte/lazer $(10,2 \%)$. De acordo, portanto, com as indicações dos vereadores, a Zona Sul compartilharia, somente em parte, problemas comuns às zonas Oeste e Norte (onde predominaram as indicações relativas aos temas vias públicas e iluminação pública).

No Centro, os temas aparecem mais pulverizados. Isso talvez ocorra porque se trata de uma área menos residencial, urbanizada e dotada de uma boa infraestrutura. Nessa região do município, quase 50\% dos temas predominantes entre as indicações foram Esporte/Lazer $(15,6 \%)$, seguido de arborização $(14,4 \%)$, iluminação pública (10\%), programa governamental $(8,9 \%)$. O tema arborização teve no Centro considerável importância, como nas Zonas Norte e Sul.

Em suma, indicações ligadas a temas de infraestrutura (consideradas aqui: vias públicas, iluminação pública e saneamento básico) predominam nas zonas Oeste (64\%) e Norte (58\%), caindo para $45 \%$ na Zona Sul e $22 \%$ no Centro. Essa distribuição reflete a carência de infraestrutura nas duas primeiras regiões cariocas.

Os órgãos públicos para os quais as indicações são encaminhadas concentram-se, coerentemente com a temática apresentada, na Secretaria Municipal de Obras e Conservação $(31,9 \%)$ e na RIOLUZ $(24,6 \%)$, seguidas da Fundação Parques e Jardins (12,4\%) e da Companhia Estadual de Trânsito (4,3\%). Enquanto órgãos de destinação das indicações, essas quatro entidades respondem por $73,3 \%$ do total.

A distribuição das categorias de análise segundo a zona do município pode refletir a situação de carência de serviços básicos e infraestrutura predominante na Zona Oeste do município e não tão grave na Zona Norte, onde a coexistência de áreas com essa carência e áreas mais "nobres" explicaria a significativa $(42,9 \%)$ presença de indicações voltadas para melhoria.

A Tabela 7, a seguir, mostra que a maioria absoluta dos vereadores cariocas eleitos em 2000 produziu indicações. Entre os 42 vereadores, 35 (83,3\%) fizeram uso desse instrumento. Fica evidente, porém, que as indicações não estão distribuídas homogeneamente entre os vereadores. A análise da Tabela

${ }^{18}$ Consideramos um "grande emissor" aquele vereador que ultrapassa 646 indicações - o equivalente a $10 \%$ da quantidade de indicações da vereadora Rosa Fernandes, que foi quem mais utilizou esse recurso legislativo. revela que, durante a legislatura 2001-2004, houve 11 "grandes emissores de indicações" 18 . Esses grandes emissores correspondem a 31,4\% dos vereadores que produziram indicações e, juntos, foram responsáveis por $83 \%$ das indicações feitas no período. Entre esses "grandes emissores", uma única vereadora - Rosa Fernandes - foi autora de quase um terço das indicações, e apenas quatro vereadores foram responsáveis por mais da metade $(52,2 \%)$ do total das indicações. 
Tabela 7 - Emissões de indicações por vereador do município do Rio de Janeiro

\begin{tabular}{lccc}
\hline Vereador & \multicolumn{3}{c}{ Indicações } \\
& Total & \% & \% acumulado \\
\hline Rosa Fernandes & 6460 & 30,6 & 30,6 \\
Luiz Carlos Ramos & 2007 & 9,5 & 40,1 \\
Romualdo Boaventura & 1415 & 6,7 & 46,8 \\
Eliana Ribeiro & 1146 & 5,4 & 52,2 \\
Jorge Babu & 1125 & 5,3 & 57,6 \\
João Cabral & 998 & 4,7 & 62,3 \\
Prof. Uoston & 955 & 4,5 & 66,8 \\
S. Ferraz & 931 & 4,4 & 71,2 \\
Paulo Mello & 926 & 4,4 & 75,6 \\
Dr. Monteiro de Castro & 892 & 4,2 & 79,8 \\
Argemiro Pimentel & 681 & 3,2 & 83 \\
Outros 24 vereadores & 3581 & 17 & 100 \\
\hline
\end{tabular}

FONTE: Câmara Municipal do Rio de Janeiro.

Com o intuito de analisar o destino das indicações dos vereadores para as zonas geográficas do município, consideramos, além dos 11 grandes emissores, outros nove legisladores que emitiram indicações no período 2001-2004: Liliam Sá e Jerominho, por estarem entre os três "médios emissores de indica-

${ }^{19}$ Consideramos um "médio emissor" aquele vereador que produziu entre 323 indicações e 645 indicações - o equivalente a $5 \%$ e $9,98 \%$ da quantidade de indicações da vereadora Rosa Fernandes.

${ }^{20}$ Antes de iniciar a carreira parlamentar, Otávio Leite participou da administração pública nas duas gestões do prefeito Marcello Alencar (1983-1986 e 19891993), quando exerceu os cargos de coordenador das administrações regionais e de secretário municipal de Governo. Para o poder Legislativo, foi eleito vereador da cidade do Rio de Janeiro por três vezes consecutivas (1992 a 2002) e, na Assembleia Legislativa, a um mandato de deputado estadual (2003-2004). Entre 2004 e 2006, foi vice-prefeito do Rio de Janeiro.

${ }^{21}$ Consideramos um "pequeno emissor" aquele vereador que produziu menos de 323 indicações - o equivalente a menos de $5,0 \%$ da quantidade de indicações da vereadora Rosa Fernandes. ções" "19; Otávio Leite ${ }^{20}$, por ser um vereador de centro-esquerda e estar entre os "pequenos emissores de indicações"21, os vereadores Edson Santos e Jurema Batista, do Partido dos Trabalhadores (PT); o vereador Eliomar Coelho do Partido Socialismo e Liberdade (PSOL), por ser o mais à esquerda no espectro ideológico dentre os partidos que tinham representação na Câmara; e os vereadores Eduardo Paes, Índio da Costa e Rodrigo Betlhem por terem surgido do centro da administração do então prefeito César Maia (eleito pelo antigo Partido da Frente Liberal (PFL)).

De acordo com a Tabela 8, adiante, entre os 11 grandes emissores, seis concentraram suas indicações na Zona Norte - S. Ferraz (92,2\%), João Cabral $(90,6 \%)$, Rosa Fernandes $(89,1 \%)$, Prof. Uoston $(87,9 \%)$, Dr. Monteiro Castro $(63,8 \%)$, Paulo Mello (54,6\%) - e cinco na Zona Oeste - Eliana Ribeiro (99\%), Argemiro Pimentel (97,7\%), Jorge Babu (96,4\%), Romualdo Boaventura (95,7\%), Luiz Carlos Ramos (93,5\%). Observe-se que nove vereadores concentraram majoritariamente, em níveis superiores a $86 \%$, suas indicações em uma única região da cidade, Zona Norte ou Zona Oeste. As exceções são o vereador Paulo Mello, que distribuiu em certa medida suas emissões entre as regiões Norte $(54,6 \%)$ e Oeste $(34,6 \%)$, contemplando ainda a Região Sul $(10,2 \%)$, e o Dr. Monteiro de Castro, cuja distribuição é semelhante à de Paulo Mello (carreia para a Zona Oeste 33,2\%, ou seja, apenas 1/3 do total das suas indicações), porém quase não contempla a Zona Sul (10,2\%).

Entre os três vereadores da lavra do então prefeito (César Maia), Rodrigo Bethlem foi o que mais produziu indicações. Tal como Liliam Sá e Jerominho, Bethlem foi um "médio emissor de indicações", responsável por 358 delas, o que corresponde a $1,7 \%$ do total do período. A Tabela 8 mostra, ainda, que Bethlem, Liliam Sá e Jerominho tiveram um padrão de emissões semelhante ao de Paulo Mello, enfatizando, entretanto, a Zona Oeste: 53,1\%, 76,5\% e $96,1 \%$ respectivamente.

Índio da Costa e Eduardo Paes, que também iniciaram suas carreiras políticas na administração César Maia, produziram muito poucas indicações. O primeiro concentrou um pouco mais de dois terços $(67,7 \%)$ das suas $65(0,3 \%)$ indicações na Região Sul. Índio da Costa chama ainda atenção por ter sido, 
Tabela 8 - Emissão de indicações por vereador e zona geográfica do município do Rio de Janeiro (em \%)

\begin{tabular}{|c|c|c|c|c|c|c|}
\hline \multirow[t]{2}{*}{ Vereador } & \multicolumn{5}{|c|}{ Zona } & \multirow[t]{2}{*}{ Total } \\
\hline & Norte & Oeste & Sul & Centro & S. I. & \\
\hline Rosa Fernandes & 89,1 & 10,6 & 0,1 & 0 & 0,2 & $100(\mathrm{~N}=6460)$ \\
\hline Luiz Carlos Ramos & 6,3 & 93,5 & 0 & 0 & 0,1 & $100(\mathrm{~N}=2007)$ \\
\hline Romualdo Boaventura & 2,1 & 95,7 & 0,1 & 0 & 2,1 & $100(\mathrm{~N}=1415)$ \\
\hline Eliana Ribeiro & 0,3 & 99 & 0 & 0 & 0,6 & $100(\mathrm{~N}=1146)$ \\
\hline Jorge Babu & 3 & 96,4 & 0,1 & 0 & 0,4 & $100(\mathrm{~N}=1125)$ \\
\hline João Cabral & 90,6 & 8,9 & 0,2 & 0,1 & 0,2 & $100(\mathrm{~N}=998)$ \\
\hline Prof. Uoston & 87,9 & 11,9 & 0,1 & 0 & 0,1 & $100(\mathrm{~N}=955)$ \\
\hline S. Ferraz & 92,2 & 6,4 & 0,8 & 0,5 & 0,1 & $100(\mathrm{~N}=931)$ \\
\hline Paulo Mello & 54,6 & 34,6 & 10,2 & 0,1 & 0,5 & $100(\mathrm{~N}=926)$ \\
\hline Dr. Monteiro de Castro & 63,8 & 33,2 & 0,4 & 0,2 & 2,3 & $100(\mathrm{~N}=892)$ \\
\hline Argemiro Pimentel & 0,4 & 97,7 & 0 & 0 & 1,9 & $100(\mathrm{~N}=681)$ \\
\hline Liliam Sá & 34,6 & 53,1 & 6,5 & 3,5 & 2,3 & $100(\mathrm{~N}=508)$ \\
\hline Rodrigo Bethlem & 19,3 & 76,5 & 2,8 & 0,3 & 1,1 & $100(\mathrm{~N}=358)$ \\
\hline Jerominho & 2 & 96,1 & 0,8 & 0 & 1,1 & $100(\mathrm{~N}=355)$ \\
\hline Edson Santos & 52,8 & 27,2 & 5,6 & 4 & 10,4 & $100(\mathrm{~N}=125)$ \\
\hline Jurema Batista & 49,3 & 39,4 & 5,6 & 1,4 & 4,3 & $100(\mathrm{~N}=71)$ \\
\hline Índio da Costa & 18,5 & 12,3 & 67,7 & 1,5 & 0 & $100(\mathrm{~N}=65)$ \\
\hline Eduardo Paes & 0 & 100 & 0 & 0 & 0 & $100(\mathrm{~N}=3)$ \\
\hline Eliomar Coelho & 50 & 50 & 0 & 0 & 0 & $100(\mathrm{~N}=2)$ \\
\hline Otavio Leite & 0 & 100 & 0 & 0 & 0 & $100(\mathrm{~N}=1)$ \\
\hline
\end{tabular}

FONTE: Câmara Municipal do Rio de Janeiro.Nota: S. I. - sem informação.

entre os vereadores do período, o que mais enfatizou a região mais rica do município. A outra terça parte, Índio da Costa distribuiu pelas regiões Norte $(18,5 \%)$ e Oeste $(12,3 \%)$. Eduardo Paes, por sua vez, produziu apenas três indicações, todas destinadas à Zona Oeste.

Segundo ainda a Tabela 8, os vereadores de esquerda também fizeram muito pouco uso das indicações. Os dois vereadores do PT tiveram padrão semelhante. A maioria das poucas indicações que Edson Santos e Jurema Batista fizeram foi destinada à Zona Norte (52,8\% e 49,3\% respectivamente), seguindo uma distribuição decrescente nas Zonas Oeste (39,4\% e 12,3\% respectivamente), Sul (5,6\% ambos) e Centro (4,0\% e 1,4\% respectivamente). Já Eliomar Coelho (PSOL) emitiu apenas duas indicações: uma para a Zona Norte, pedindo o asfaltamento de uma rua à Secretaria Municipal de Obras (SMO), e outra destinada à Zona Oeste, solicitando o início das obras de água e esgoto em um conjunto habitacional à Companhia de Águas e Esgoto (Cedae).

${ }^{22}$ Não sabemos, de fato, ainda se o vetor esquerda-direita é o mais importante ou se o mais relevante é o vetor situação-oposição. Por isso, não sabemos quais seriam as implicações quando esses dois fatores não se sobrepõem. Consequentemente, um dos desdobramentos desta pesquisa será “cruzar" os dados expostos aqui com outras variáveis (número de mandatos, experiência legislativa, proporção de votos, origem sociográfica do vereador etc.). Assim, poderemos identificar tendências não necessariamente vinculadas
$\mathrm{O}$ pouco uso das indicações entre os vereadores de esquerda talvez tenha a ver com a concepção que estes têm da representação política ${ }^{22}$. Em 2008, perguntada pelo jornal $O$ Globo o que a diferenciava dos demais candidatos ${ }^{23}$, Jurema Batista deu uma resposta na qual enfatiza mais o papel de "fiscal do Executivo" do que de "ouvidor do povo". Eis o que ela disse: "Jurema: Vereador não é para ter centro social, não é para fazer benesses. Vereador é para fiscalizar o Executivo e fazer leis de interesse público. Se a Câmara estivesse atenta ao seu papel, não teríamos um problema grave como foi o da dengue. Quero fiscalizar o orçamento municipal, para que o dinheiro atenda aos interesses da população carioca" (Jurema Batista, candidata a vereadora pelo PT, 2008).

Contudo, o vereador que menos produziu indicações foi o tucano Otávio Leite, entre os que produziram. Durante todo o seu mandato, ele emitiu uma única indicação, destinada à Zona Oeste. Curioso é que esse vereador mencio- 
ao aspecto ideológico do parlamentar.

${ }^{23}$ A pergunta foi: "O que a senhora acha que a diferencia dos outros candidatos?". na entre as funções do político moderno a de "[...] constituir-se em advogado de causas comunitárias. Ser alguém aberto a receber permanentemente demandas vindas da sociedade, sejam individuais ou coletivas. Isto é, reivindicações ou propostas de soluções para problemas que lhe são postos ou colocados. Ser um interlocutor da sociedade junto aos poderes públicos e encaminhar questões em busca de resultados" (Leite 2011).

Apesar de Otávio Leite afirmar que o político moderno tem entre as suas funções a de ser advogado de causas comunitárias, parece que, como vereador, no período 2001-2004, ele preferiu privilegiar as outras duas listadas por ele: "A primeira delas, legislar. Isto é, propor projetos de lei com objetivo de criar novos direitos e deveres, atualizar a legislação, votar os projetos demandados pelo prefeito ou por seus colegas parlamentares. Logo, a dimensão primeira do trabalho parlamentar é esta: o ato de legislar, decidir a construção de normas jurídicas, tarefa esta que requer discernimento e senso de justiça.

"A segunda função do homem público é a de fiscalizar o Poder Executivo, de acompanhar seus passos na realização de obras ou intervenções e na prestação de serviços públicos. Nesse aspecto, eu acrescentaria a definição das diretrizes que caberá ao Poder Executivo seguir. E isso se firma através da Lei de Diretrizes Orçamentárias e da Lei Orçamentária propriamente dita. Votá-las, bem como acompanhar a execução orçamentária, também faz parte do dever de um político moderno" (idem).

As falas transcritas acima sugerem que precisamos de mais pesquisas sobre a relação entre a concepção que o vereador tem da representação política e sua atividade parlamentar efetiva. Esse deverá ser um dos desdobramentos da presente pesquisa.

Tem sido recorrente a abordagem do problema da representação política e sua suposta crise (Power \& Jamison 2005; Avritzer 2008), a partir da reconsideração do alardeado problema do déficit de representatividade do sistema político democrático e das proposições de novos incrementos democráticos alternativos ou complementares ao modelo representativo partidário eleitoral (Lavalle \& Vera 2010). A sustentação do diagnóstico repousa na suposta incapacidade de a democracia representativa de fato representar os representados ou alcançar certo ideal democrático de soberania popular. De outra parte, um dos motes utilizados para caracterizar a crise da representação contemporânea é a convivência desta com formas alegadamente não virtuosas de mediação política, a exemplo do clientelismo.

$\mathrm{O}$ atendimento a demandas de tipo paroquial, como as de que estamos tratando, é frequentemente relacionado com a competição eleitoral. A intermediação de interesses paroquiais é comumente interpretada como prática de clientela, com fins "eleitoreiros". Nessa chave, uma população carente de toda sorte de serviços públicos seria manipulada por políticos astutos. Em direção contrária, certa literatura tem em comum o entendimento de que o fenômeno do clientelismo é endógeno à organização do poder (Diniz 1982; Gay 1998; Carvalho 1999; D'Ávila Filho 2000; 2008; Bahia 2003). O que se troca é apoio político e lealdade por benefícios patrimoniais, máquina política por compromisso. Em todas as sociedades, a autoridade pública legítima organiza-se em bases patrimoniais. Em linguagem weberiana, a disputa pelo poder é a disputa pelos instrumentos da autoridade pública. Clientelismo, nessa chave, torna-se 
${ }^{24}$ Investigar as tensões possíveis entre a perspectiva clássica de ideal democrático calcado na soberania popular e a fórmula moderna da democracia representativa exige um esforço de investigação que não é o objetivo deste trabalho, e que nos leva a pensar os caminhos que penetram uma incessante busca por mecanismos de aproximação entre o demos e o kratos. Tais aproximações podem ser vistas segundo um critério "autorizatório" ou delegativo, como proposto por Pitkin (1967) ou mesmo à luz de um princípio de distinção segundo Manin (1995). Pode-se considerar, também, que foi a representação que democratizou a democracia, como recentemente analisado por Urbinati (2006) ou propor uma teoria mais abrangente, como Rosanvallon (2006), que considera a importância que as novas práticas participativas podem refletir em um ambiente social que almeja ter em seus representantes uma maior expressão de suas diversas possibilidades de identidades sociais (cf. D'Ávila Filho \& Faria 2009). um conceito que descreve uma relação de troca política. O clientelismo apresenta-se como estratégia moderna de obtenção de benefícios por parte dos atores sociais minimamente organizados e desejosos de auferir determinados benefícios, os clientes, com os detentores legítimos dos benefícios patrimoniais, materiais ou simbólicos, seus patroni (D'Ávila Filho 2008). O estudo apurado das redes criadas em torno das indicações possibilitaria elucidar pontos de contato entre a representação democrática e as trocas clientelistas, ao explorar as "zonas cinzentas" em que as duas características do que estamos considerando aqui como clientelismo podem se manifestar: seu caráter mimético confundindo-se com o meio democrático - e o metamórfico - sua capacidade de assumir formas variadas de acordo com o terreno no qual opera (D'Ávila Filho, Jorge \& Alves 2004; D’Ávila Filho 2008). Esse, porém, não é o objetivo deste texto, mas sim um desdobramento possível da pesquisa em andamento.

Neste trabalho, chamamos a atenção não só para o caráter legal (regimental) das indicações, como, também, para seu uso como artefato de negociação, um mecanismo de intermediação em uma tríade de interesses mútuos. Diante do exposto, é possível dizer que as indicações constituem, também, um mecanismo significativo de representação democrática ${ }^{24}$. Em uma direção oposta, há alguma percepção canônica da ideia de representação política, a hipótese a que a análise das indicações conduz-nos é a de que as noções do sentido e significado da ideia de representação política são múltiplas e variadas, como nos sugerem os diferentes perfis de atividade legislativa até aqui analisados. Esses diferentes sentidos ou significados ordinários para a representação política seriam os produtos ofertados a um eleitor também múltiplo que adere ou compra distintos significados para a representação política local. Dessa forma, podemos dizer que o que está em disputa não são apenas os afazeres da representação, as ações propostas ou manifestas por um candidato, mas a própria atribuição de sentido à ideia ordinária, usual, de uma boa representação política para além dos cânones acadêmicos.

A hipótese de que os vereadores utilizam as indicações para realizar trocas entre os eleitores, por um lado, e o poder Executivo, por outro, e desta forma estabelecer sua conexão eleitoral, é comprovada parcialmente. As evidências desse comportamento político foram comprovadas pelos dados que revelaram que: $(i)$ os vereadores fazem uso das indicações de modo que o bem ou serviço público seja realizado pelo Executivo e entregue à população ainda durante o período de seu mandato. Somente assim poderão utilizá-las em sua propaganda eleitoral; (ii) as indicações visam fornecer um bem ou prestar um serviço público que supriria as carências identificadas pelos seus autores ou pelos próprios eleitores que vivem na área beneficiada.

Os dados expostos neste trabalho, contudo, sugerem outras questões relevantes para compreendermos a importância real das indicações na estratégia eleitoral dos vereadores cariocas. A primeira questão é se as regiões geográficas para as quais os vereadores concentram suas indicações são aquelas das quais extrairiam a maioria de sua votação. Neste caso, políticos com uma votação mais concentrada territorialmente tenderiam a utilizar mais esse dispositivo legislativo do que aqueles com uma votação mais dispersa. Isso explicaria por que determinados políticos, apesar de admitirem que os políticos têm entre suas funções a de serem advogados de causas comunitárias, não fazem indicações ou, quando fazem, são autores de pouquíssimas indicações. Não haveria assim uma identificação clara entre o comportamento legislativo no que tange às indicações e às siglas partidárias. A verificação dessas questões nos permi- 
tirá ainda saber se uma concepção de representação menos centrada na ideia de "ouvidoria" atravessa os partidos.

Paulo M. d'Avila Filho (paulodavilaf@yahoo.com.br) é Doutor em Ciência Política pelo IUPERJ e professor do departamento de Ciências Sociais da UERJ.

Vladimyr Lombardo Jorge (vljorge@uol.com.br) é Doutor em Ciência Política pelo IUPERJ e professor do Departamento de Ciências Sociais da UFRRJ.

Paulo Cesar G. de Cerqueira Lima (paulogreenhalgh@uol.com.br) é Doutor em Engenharia de Produção pela COPPE/UFRJ e professor do Departamento de Ciências Sociais da PUC-Rio.

\section{Referências bibliográficas}

Referências

Ackel Filho, D., 1992. Município e prática municipal à luz da Constituição Federal de 1988. Rio de janeiro: RT.

Avritzer, L., 2008. Instituições participativas e desenho institucional: algumas considerações sobre a variação da participação no Brasil democrático. Opinião Pública, 14(1), pp. 43-64.

Amorim Neto, O. \& Santos, F., 2001. A conexão presidencial: facções pró e antigoverno e disciplina partidária no Brasil. Dados, 44(2), pp. 291-321.

Andrade, R.C., ed., 1998. Processo de governo no Município e no Estado. São Paulo: EDUSP.

Bahia, L.H.N. 2003. O poder do clientelismo: raízes e fundamentos da troca política. Rio de Janeiro: Renovar.

Baquero, M., 1997. Novos padrões de comportamento eleitoral: pragmatismo nas eleições municipais de 1996 em Porto Alegre. In M. Baquero, ed. A lógica do processo eleitoral em tempos modernos: novas perspectivas de análise. Porto Alegre: UFRGS.

Carvalho, J.M., 1999. Mandonismo, coronelismo e clientelismo: uma discussão conceitual. In J. M. Carvalho, ed. Pontos $e$ bordados. Escritos de História e Política. Belo Horizonte: UFMG.

Cervi, E.U., 2009. Produção legislativa e conexão eleitoral na Assembleia Legislativa do estado do Paraná. Revista de Sociologia e Política, 17(32), pp. 159-177.

D’Ávila Filho, P.M., 2000. Democracia, clientelismo e cidadania: a experiência do orçamento participativo no modelo de gestão pública da cidade de Porto Alegre. Tese de Doutorado. Rio de Janeiro: Instituto Universitário de Pesquisas do Rio de Janeiro.

2005. Estudos legislativos municipais no estado do Rio de Janeiro: produção legislativa e intermediação de interesses e guia do regimento interno da CMRJ. Cadernos de Sociologia e Política, 6, pp. 3-57.

2008. Assimetria e trocas políticas locais: apontamentos preliminares de uma pesquisa sobre produção legislativa e dinâmica política municipal. Desigualdade e Diversidade, 2, pp. 79-94.

D’Ávila Filho, P.M. \& Faria, A.M.T., 2009. O Social e o político em movimento: novas agendas para a representação política no Brasil. In $14^{\circ}$ Congresso Brasileiro de Sociologia. Rio de Janeiro.

D’Ávila Filho, P.M.; Alves, A. C. \& Jorge, V.L., 2002. Mecanismos de intermediação de interesses público/privado nos municípios do estado do Rio de Janeiro. In $26^{\circ}$ Encontro Anual da Anpocs. Caxambu.

2004. Orçamento público municipal e mecanismos de intermediação de interesses. In $4^{o}$ Encontro Nacional da Associação Brasileira de Ciência Política. Rio de Janeiro.

De Certeau, M., 2004. A invenção do cotidiano. V. 1. Petrópolis: Vozes.

Diniz, E., 1982. Voto e máquina política. Patronagem e clientelismo no Rio de Janeiro. Rio de Janeiro: Paz e Terra.

Figueiredo, A.C. \& Limongi, F., 1999. Executivo e legislativo na nova ordem constitucional. Rio de Janeiro: FGV. 2008. Política orçamentária no presidencialismo e coalizão. Rio de Janeiro: FGV.

Fischer, T., ed., 1997. Gestão contemporânea: cidades estratégicas e organizações locais. Rio de Janeiro: FGV.

Foucault, M., 1984. Vigiar e punir. $3^{\mathrm{a}}$ ed. Petrópolis: Vozes.

Gay, R., 1998. Rethinking Clientelism: Demands, discourses and practices in contemporary Brazil. Conecticut College. Mimeo.

Kuschnir, K., 2000a. O cotidiano da política. Rio de Janeiro: J. Zahar. 2000b. Eleições e representação no Rio de Janeiro. Rio de Janeiro: Relume Dumará. 2007. Antropologia da política. Rio de Janeiro: J. Zahar.

Lavalle, A. \& Vera, E., 2010. Precisiones conceptuales para el debate contemporaneo sobre la innovación democrática: participación, controles sociales y representación. In A. Lavalle \& E. Vera, eds. La innovación democrática en América Latina: Tramas y mundos de la representación, la participación y el control social. Ciudad del México: Publicaciones de la Casa Chata.

Leite, O., 2011. O papel do político no mundo moderno. Disponível em http://www.otavioleite.com.br/perfil_papelpolitico. asp. Acesso em: 24.jan.2014. 
Macintyre, A., 1991. Justiça de quem? Qual racionalidade? São Paulo: Loyola.

Manin, B., 1995. Principes du gouvernement representatif. Paris: Calmann-Lévy.

Marques, E. C., 2000. Estado e redes sociais: permeabilidade e coesão nas políticas urbanas no Rio de Janeiro. Rio de Janeiro: Revan.

2003. Redes sociais, instituições e atores políticos no governo da cidade de São Paulo. São Paulo: Annablume.

2010. Redes sociais, segregação e pobreza. São Paulo: Unesp.

Pereira, C., 2002. What Are the Conditions for the Presidential Success in Legislative Arena? The Brazilian electoral connection. Tese de Doutorado. New York: New School University.

Pereira, C. \& Rennó, L., 2001. O que é que o reeleito tem? Dinâmicas político-institucionais locais e nacionais nas eleições de 1998 para a Câmara dos Deputados. Dados, 44(2), pp. 133-172.

2007. O que é que o reeleito tem? O retorno: o esboço de uma teoria da reeleição no Brasil. Revista de Economia Política, 27(4), pp. 664-683

Pitkin, H.F., 1967. The Concept of Representation. Berkeley: University of California.

Power, T.J. \& Jamison, G. D., 2005. Desconfiança política na América Latina. Opinião Pública, 11(1), pp. $64-93$.

Rosanvallon, P., 2006. La contre-démocratie. Paris: Editions du Seuil.

Santos, F., 1997. Patronagem e poder de agenda na política brasileira. Dados, 40(3), pp. 465-492.

2001. O Poder Legislativo nos Estados: diversidade e convergência. Rio de Janeiro: FGV.

2003. O Poder Legislativo no presidencialismo de coalizão. Rio de Janeiro-Belo Horizonte: UFMG.

Schumpeter, J., 1984. Capitalismo, Socialismo, Democracia. Rio de Janeiro: J. Zahar.

Urbinati, N., 2006. O que torna a representação democrática? Lua Nova, 67, pp. 191-228.

Wittgenstein, L., 1994. Investigações filosóficas. $2^{\mathrm{a}}$ ed. Petrópolis: Vozes.

\section{Outras fontes}

CÂMARA MUNICIPAL DO RIO DE JANEIRO. 2004. Banco de indicações dos vereadores do Rio de Janeiro.

Jurema Baptista, candidata a vereadora pelo PT. 2008. O Globo, Rio de Janeiro, 24.ago. Disponível em: http://oglobo.globo. com/pais/eleicoes-2008/jurema-batista-candidata-vereadora-pelo-pt-5002337. Acesso em: 24.jan.2014.

PNUD. 2000. Índice de desenvolvimento humano municipal (IDH-M), por ordem de IDH, segundo os bairros ou grupo de bairros. Disponível em: http://www.pnud.org.br/pdf/Tabela\%206.2.22\%20IDH\%20bairro\%2091_00-15_12_03.xls. Acesso em: 24.jan.2014.

\section{ABSTRACT}

In this study the authors analyse the relationship between the society and local authorities in the Legislative power, taking the requests (indicações) of council representatives of Rio`s Municipal Chamber (Câmara Municipal do Rio de Janeiro) to agencies of the municipal government and the city`s Mayor`s Office as subject, between 2001 and 2004. The objective is to analyse the political-electoral dynamics considering the strategies adopted by the representatives to get them re-elected or to occupy a different public post. The hypothesis of this study is that the political legislators use the requests in order to intermediate Executive/voter's relationship and by doing so build their electoral connections. The info used in this study is secondary and qualitative and is built on an Access Ms base and was obtained from Rio de Janeiro`s Council Representatives requests data bank. Its content consists of the characteristics of the requests made by the representatives, such as the year of issue and the specific area of the city, between 2001 and 2004. The base, which was transferred to Excel, was refined and in it each request was categorized according to investments, maintenance or immaterial services it was destined to. The tables of simple frequency and contingency were generated in the SPSS package. The data which characterizes the appointments was assembled and patterns of timing, kind and their final destination in the city of Rio de Janeiro for their emission have been observed. The number of requests available is the total number of those issued by the Municipal Chamber of Rio de Janeiro in the above mentioned period. They represent both the studied population in a specific period and a thorough sample of the ample and dynamic historical process that generates these requests. Submitted to descriptive analysis and the $\chi^{2}$ test the data partially confirmed the research hypothesis. Firstly, it suggests that the council representatives are inclined to use the requests so that the welfare or public service is built and delivered by the executive power within their mandate. Secondly, by doing that, the representative's aim at providing welfare or public service that will cover the public needs detected by themselves or by the voters. The study also suggests that the requests generally considered not so relevant or important by some political scientists and the press as a whole can be important tools in the formation of political networks and should be further analysed. The data still points to the need for new researches to ratify if requests are in fact mainly assigned to the council representatives` electoral areas to better understand why not all political representatives use requests with the same frequency. The hypothesis still to be checked is: Do politicians with more locally concentrated votes tend to use this prerogative more often than those who have more global votes? 
KEYWORDS: Municipal Chamber; representatives' requests; electoral connections; interest intermediation; Executive-Legislative relationship 